\title{
Lipid Peroxidation, Antioxidant Status and some Blood Components in $\beta$-Thalassemia
}

\author{
Owayes M. Al-Hassany \\ Department of Biology \\ College of Science \\ Mosul University
}

(Received 31 / 8 / 2009; Accepted 2/ 11 / 2009)

\begin{abstract}
Information pertaining to the lipid peroxidation and antioxidant status of patients with $\beta$-thalassemia has been scantly. We report here the results of our efforts in evaluation of some biochemical parameters such as lipid peroxidation, antioxidant, renal function and ferritin in sera and some blood component such as Red blood cell count, estimation of hemoglobin, packet cell volume, mean corpuscular volume, mean corpuscular hemoglobin and mean corpuscular hemoglobin concentration of a group who have $\beta$-thalassemic major $(n=25)$. As a result of the research serum malondialdehyde (MDA), ferittin, concentration of serum urea and creatinine levels in these patients were found to be increased significantly when compared to the disease free control $(p \leq 0.05)$. Conversely levels of reduce glutathione and vitamin $\mathrm{C}$ shown to be decreased as compared to the control group $(\mathrm{n}=15)$. The blood component measurement in this study showed significantly decrease comparing with the control group.
\end{abstract}

\section{تأثير الإصلبة بالفالميميافي طستوى بيروكسة الهن وعددمن مضادل الكسة غير الانزيمية في مطل الم المانهص}

المعلوملت التي تتعلق ببيروكسة الدهن ومستوى مضادات الألمسة مع الإصابة بم ـرض الثللمس يميا نوعاما ضiئيلة. ونظطرق في هذه الدرلسة إلى قيلس بعض المتغيرات الكيموحيوية ف مي مـ صل الـ ـم مث لـ بيروكسة الدهن و الفرتين وعدد من مضادات الأكسة غير الأذزيمية وظظاف الكلية بالإضفافة إلى عدد من

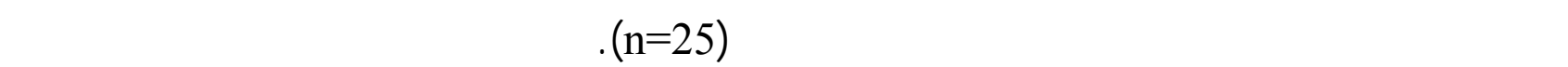

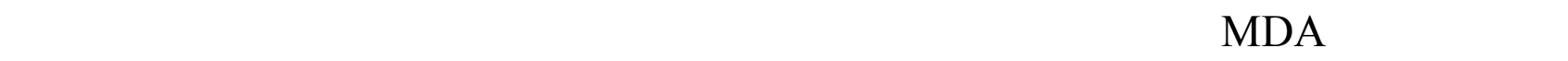

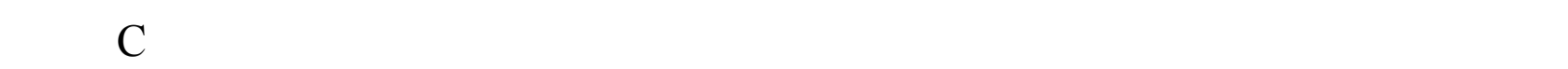

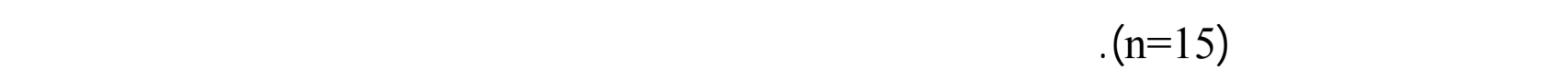
الأصحاء. 